\title{
Evolution of Mustang Graben, Tibet Himalayas, due to eastward extrusion of Tibet Plateau in and after the Last Glacial Age
}

\author{
Hiroshi Yagi†*, Hideaki Maemokuł, Yasuhiro Kumaharał, Takashi Nakatał and Vishnu Dangol§ \\ † Lab. Geography, Yamagata University, Kojirakawa, Yamagata, 990-8560, JAPAN \\ ¥ Institute of Geography, Hiroshima Universitys, JAPAN \\ $\$$ Institute of Geology, Trichandra Campus, Trivbhan University, NEPAL
}

*To whom correspondence should be addressed.E-mail: yagi@kescriv.kj.yamagata-u.ac.jp

\begin{abstract}
Mustang Graben is a NS trending longitudinal depression located in Tibet Himalayan Zone just behind the Higher Himalayas of Nepal (Figure 1). Its height is 3,000 to $4,000 \mathrm{~m}$ asl. surrounded by Tibetan Himalayas of which summit level is 5,000 to 7,000 $\mathrm{m}$ asl. Its width and length are less than ten kilometers and more than fifty kilometers, respectively. Kali Gandaki River originates from the uppermost course of the Mustang valley and flows through the valley. The river joins to the Ganga, forming the deepest transverse valley across the Higher Himalayas in the world. Development of such a graben in Tibetan Plateau is attributed to EW tensile stress field resulted from eastward extrusion of the Tibetan Plateau (Molnar and Tapponier 1975). There are some chronological studies on Takkhola Formation, burring Mustang Graben, and studies on relation between upheaval of Himalaya Range and deposition of Takkhola Formation (Yoshida et al. 1984). Hurtado et al. (2001) reports neotectonics of the Takkhola Graben. There are, however, no detail studies based on a field research in the upper Mustang about the most recent active faulting such as deformation of fluvial terraces and glacial landforms developed in the late Pleistocene or Holocene.

The authors (Yagi, Maemoku and Dangol) carried out a field study in the upper Mustang valley up to the border between Nepal and Tibet in Sept. 2002. This study also depends on elaborate interpretation of aerial photographs on scale of $1 / 50,000$ over the Mustang Graben with special reference to terrace classification and active faults.
\end{abstract}

Fluvio-glacial terraces as time markers

Kali Gandaki River is an entrenched valley with more than 12 levels of terraces. The terraces are outwash plains continuing from moraine, fans and fluvial terraces. Development of those terraces was caused by complex of detritus supply due to glaciation, hydrological and tectonic conditions in this valley in the late Pleistocene and Holocene. There are some previous studies on geomorphological history along the Kali Gandaki River in the lower course from Kagbeni (Iwata et al. 1982, Iwata 1984, Hasegawa and Sasaki 1998, Hurtado et al. 2001).

This study tentatively classified those terraces into three groups; Higher terrace group, Middle terrace group and Lower terrace group, respectively. They are correlated as follows; Higher terrace group: MIS 4-3, Middle terrace group: MIS 2 and Lower terrace group: MIS 1, respectively, on the basis of their continuity along Kali Gandaki River, relative chronological level of terraces and radio carbon data obtained from terrace deposits (Iwata 1984, Hasegawa and Sasaki 1998, Hurtado et al. 2001). The higher terrace group is at least older than 22,770 yrs BP (Hasegawa \& Sasaki 1998). This study also reports new radio carbon data from the Lowest terrace (L II ) of 2,605 Cal BP just near Lo Mantang. Elder terraces are distributed in the lower course side around Jomoson, and younger terraces are distributed in the upper course side over the study area. Such chronological feature implies glaciation in the Holocene age in the upper Mustang area.

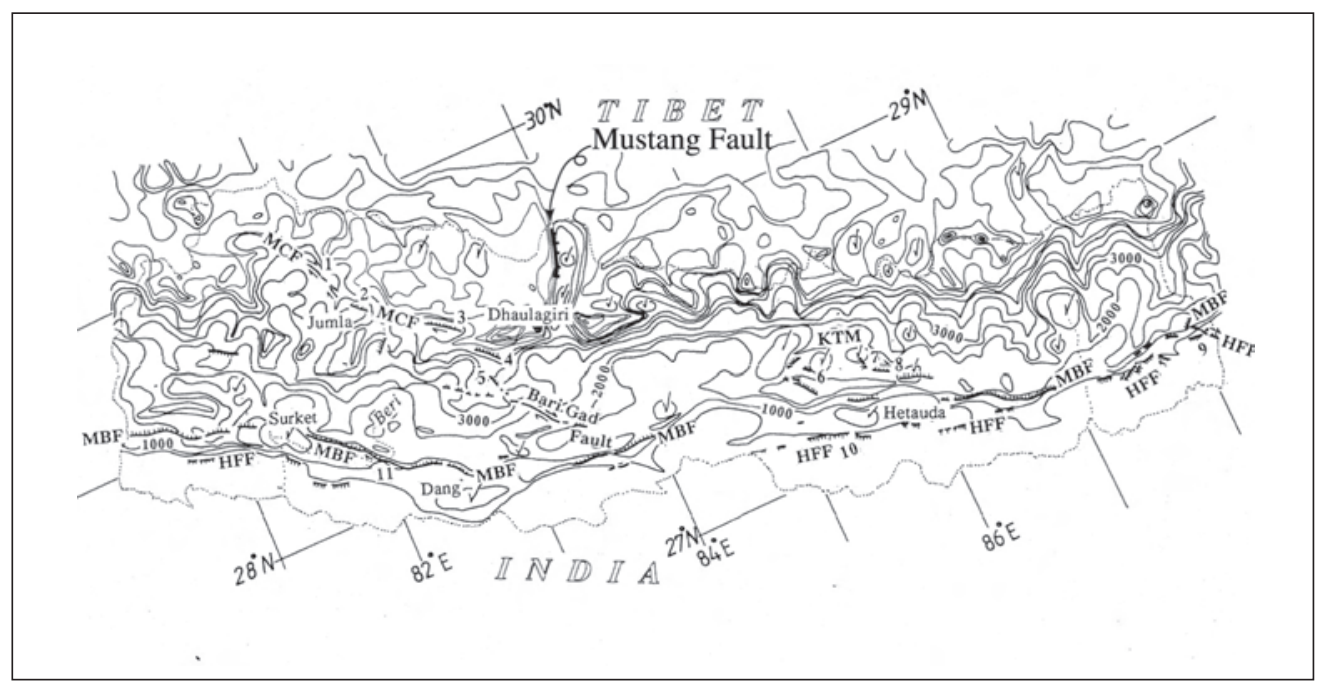

FIGURE 1. Location of Mustang Graben and distribution of active faults in the Nepal Himalayas 

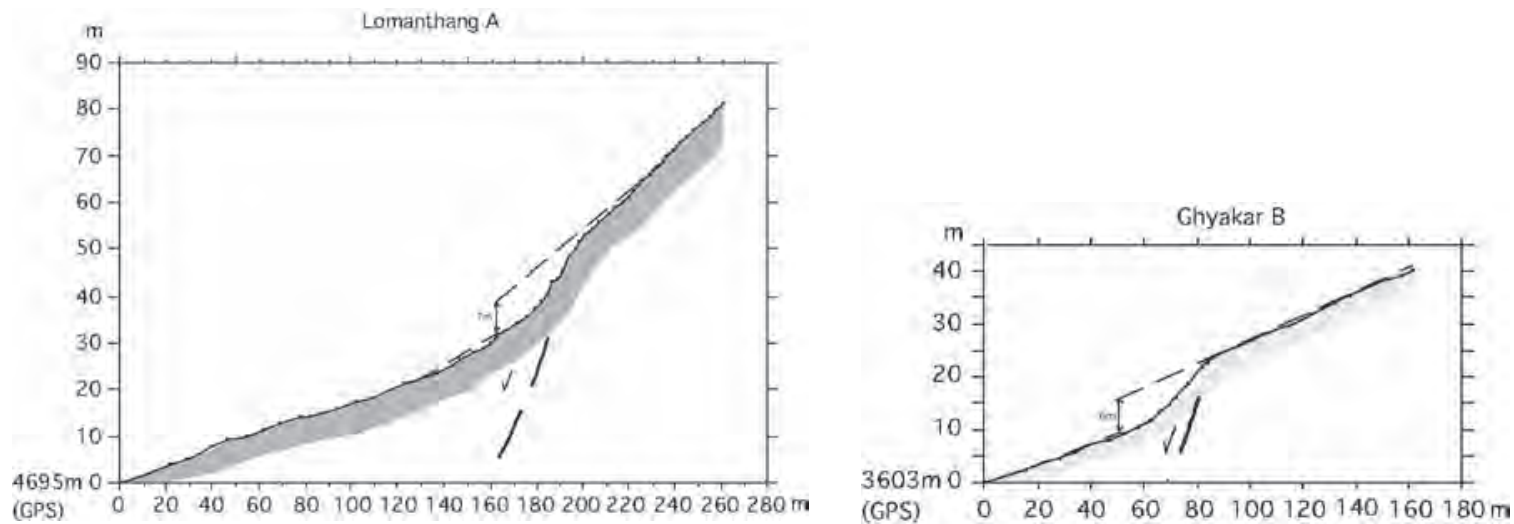

FIGURE 2. Geomorphological profiles of deformed fan surfaces due to active faulting

\section{Mustang Fault}

Distinct topographic contrast occurs along a foot line between the Graben and the surrounding mountains of Tibet Himalaya. Moraines and fan surface of outwash plain origin have been sometimes interrupted their geomorphological continuity by low relief scarplets perpendicular or oblique to the surfaces declination, where the foot line crosses the recent geomorphological surfaces. The scarplets usually occur on the Middle and Lower terrace groups and face to east (Figure 2). They are traceable along the western foot line as long as fifty kilometers, though they occur sometimes fragmentarily. Such phenomena imply that these scarplets were caused by active faulting in and after the last Glacial Age. The authors call this active fault as Mustang Fault. Outcrop at left bank of the Ghilunpa Khola shows active faulting of river terrace deposits, dipping down to the east by high angle fault of $70-80$ degrees. Consequently, sense of Mustang Fault is normal, down-throwing to the east. Lateral displacement of the topographic surface is not found, though Hurtado et al. (2001) describes the fault (Dangardzong fault) is a dextral strike slip in sense.

The authors surveyed tectonic deformation of topographic surfaces where fault scarps are clear. The highest profiles are obtained at 4,700 $\mathrm{m}$ asl. near the border. Dislocation of the surfaces ranges from 3.5 to $7 \mathrm{~m}$. Vertical slip rate is higher in the north compared with that in southern part of the Graben. Valley side fault of normal sense is also found in the Thakkhola formation, Plio-Pleistocene sediments, near Dhakmar village in central part of the Graben. Deformation of the Thakkhola formation is more than fifty meters. These phenomena indicate that Mustang Graben has been formed by a tensile stress field of EW direction after Pliocene and evolved until Holocene. Extrusion of Tibet affects the Tibet Himalayan zone and has been continuing throughout the late Pleistocene to the Holocene.

\section{References}

Molnar P and P Tapponier. 1975. Cenozoic tectonics of Asia: Effects of a continental collision. Science 189: p 419-426

Yoshida M, Y Igarashi, K Arita, D Hayashi and T Sharma. 1984 Magnetostratigraphic and pollen analytic studies of the Takmar series, Nepal Himalayas. Journal of Nepal Geological Society (Special issue) 4: 101-20

Hurtado JM, KV Hodges and KX Whipple. 2001. Neotectonics of the Thakkhola graben and implications for recent activity on the South Tibetan fault system in the central Nepal Himalaya. GSA Bulletin 113(2): $222-40$

Iwata S. 1984. Geomorphology of the thakkhola-Muktinath region, central Nepal, and its late Quaternary history. Geographical Report of Tokyo Metropolitan Univ 19: 25-42

Hasegawa Y and A Sasaki. 1998. Radio carbon data bearing on a lateral moraine distributed at Pandha Khola, a tributary of Kaligandaki River Nepal Himalaya, Quaterly J Geography. 50(3): 220-21 (in Japanese) 